\title{
O QUE HÁ DE MAGIA NA POESIA? COMPARANDO POÉTICAS DO ENCANTAMENTO
}

WHAT IS THERE OF MAGIC IN POETRY? COMPARING POETICS OF ENCHANTMENT.

EdUARDo GUeRreIRo BRITo Losso ${ }^{(*)}$

\begin{abstract}
RESUMO
Teóricos da poética frequentemente aproximam poesia de mística, ao mesmo tempo que distinguem o poeta do místico. Dizem que o poeta medita na exterioridade e o místico na interioridade, mas especialistas nos grandes místicos afirmam que não há, neles, a separação entre busca espiritual e contemplação da materialidade. De qualquer modo, o místico busca a experiência suprassensível. Por isso, talvez seja mais pertinente examinar as aproximações entre poesia e magia.Ao longo da história da poética, elas são abundantes. Examinamos três ocorrências importantes nessa história: em Platão, Martin Opitz (primeiro poetólogo alemão) e Novalis. Ao compará-las, percebemos que a magia parece ser essencial à origem e atuação da poesia, mas por diferentes motivos.
\end{abstract}

Palavras-Chave: Magia. Poesia. Poética. Platão. Novalis.

\section{ABSTRACT}

Theorists of poetics move often poetry closer to mysticism, while put the poet apart from the mystic. They affirm the poet meditates on externals and the mystic on the interiority, but experts claim that there isn't in the great mystics the division between spiritual pursuit and contemplation of materiality. However, mystics seek supersensible experience. Therefore, it may be more relevant to examine the similarities between poetry and magic. Throughout the history of poetics, they are plentiful. We examine three important milestones in this history: Plato, Martin Opitz (first German poetologist) and Novalis. By comparing them, we realized that magic seems to be essential to the origin and the action of poetry performance, but for different reasons.

KEYWORDS: Magic. Poetry. Poetic. Plato. Novalis.

\section{DA MÍSTICA À MAGIA DA POESIA}

Diversos teóricos da poética da primeira metade do século XX observaram a proximidade entre poesia e mística. Apontam nela um não sei quê de divino. Exemplos: "Imagino, sobre a essência da Poesia, que ela tenha, de acordo com as diversas naturezas dos espíritos, valor nulo ou importância infinita: o que a

\footnotetext{
${ }^{(*)}$ Eduardo Guerreiro Brito Losso é professor adjunto de Teoria Literária do Programa de Pós-Graduação em Ciência da Literatura da UFRJ desde 2014, tendo sido professor de Teoria da Literatura da UFRuralRJ de 2009 a 2014. Publicou vários artigos sobre a relação entre mística e a literatura, mídias e mudança da percepção, música pop e valor estético, prática poética e indústria cultural, escrita e linguagem, poesia e filosofia. Fez parte da organização dos livros Diferencia minoritaria en Latinoamérica de 2008, pela editora alemã Georg Olms; e O carnaval carioca de Mário de Andrande, Azougue, 2011. Publicou o livro: Ciranda da poesia-Renato Rezende, EdUERJ, 2014.
} 
assimila ao próprio Deus" (VALÉRY, 1991 [1935], p. 179); "o fenômeno lírico não se aproxima do místico?” (STAiger, 1975 [1946], p. 60). O que é "mística”, ou o "divino", não parece ser, contudo, algo muito claro para eles. Por vezes, para caracterizar a poesia moderna, misturam conceitos como religião, magia, mística, alquimia. Ainda assim, fazem questão de diferenciar o poeta do místico, depois de assinalarem a aproximação: "O poeta lírico comove-se, enquanto o místico conserva uma serenidade imperturbável em Deus" (STAiger, 1975, p. 61); Goethe "é também um místico, mas um místico de um tipo singular, inteiramente devotado à contemplação da exterioridade" (VALÉRY, 1991 [1932], p. 44). Aqui, o "místico puro" é alguém imerso na interioridade, sem nenhum desejo de contato com o mundo sensível. Logo, a mística da lírica moderna seria uma espécie de recolhimento no sensível, uma meditação na paisagem, uma atenção à "tonalidade afetiva" (Stimmung, STAIGER, 1975, p. 15, 23, 26, 29).

Parece que esse tratamento da questão tem sido recorrente. Quando se lê artigos recentes que pensam tal relação, é comum encontrar esse pressuposto teórico. Para garantir a diferença entre as duas figuras (poeta e místico) essa visão desconsidera o quanto o místico medita nos elementos da natureza, o quanto o seu afastamento (temporário, é bom lembrar) da mundanidade dos homens é um mergulho na contemplação da natureza, observando atentamente a criação divina e retirando, daí, diversos símbolos e alegorias poéticas de grande alcance. Só para citar dois nomes clássicos tanto da poesia quanto da mística ocidental, São João da Cruz e Silesius não são menos sensíveis nem atentos à materialidade do que qualquer outro poeta moderno. "A TRINDADE NA NATUREZA. Que Deus seja trino, cada erva te aponta: enxofre, sal e mercúrio são vistos em um" (Silesius, 1905, p. 35), isto é: Deus está nas mínimas coisas da natureza, e os elementos constitutivos desta (segundo Paracelso, SilEsius, 1996, p. 59; LAUFHÜTTE, 2006, p. 261) são unidos pela sua trindade.

As diferenças entre místicos e poetas modernos se dão mais por terem diferentes perspectivas históricas do que por encarnarem supostos princípios absolutos de uma mística ascética pré-moderna.

É verdade que o místico, seja poeta ou não, busca a "noite escura", busca um estado de participação com o divino além dos sentidos. Contudo, no percurso ascensional, os "gostos de Deus" de Santa Teresa preenchem todo o ser, vêm de uma nascente divina e atingem até mesmo o corpo: "todo o ser exterior usufrui desse gosto e suavidade” (Castelo interior, ÁviLA, 2001, p. 477). 
Faustino Teixeira tem insistido nesse aspecto: em Teresa, "não há como excluir o corpo da experiência espiritual: corpo e espírito oram simultaneamente", e cita a passagem chave do Livro da vida: "Não somos anjos, pois temos um corpo" (TEIXEIRA, 2014, p. 9; Ávila, 2001, p. 145). Só contemplando as maravilhas da criação e aceitando deleites interiores que beneficiam também o corpo, é possível o trabalho espiritual; ademais, não há distinção possível em saber se ele é efetuado pelo corpo ou espírito. Também Maria Clara Bingemer corrobora: "Essa consciência do corpo como locus, onde a experiência mística se dá, aparece tanto em sua prosa, notavelmente na autobiografia 'Vida', como em sua lírica, que se destaca pelo pathos que a atravessa." (BINGEMER, 2015)

O que pode ser mais produtivo é pensar se algumas características da poesia moderna que retomam elementos religiosos não estão, necessariamente, ligadas a uma busca de desprendimento do corpo e da matéria. Ao contrário, se ela quer mesmo é imergir neles, agir sobre eles (em vez de contemplá-los), talvez até com propósitos de incremento de potência vital, sem que isso deixe de ser um percurso espiritual, a palavra correta para isso não é: magia? E, se for o caso, não vale a pena distinguir, na medida do possível, a relação da poesia com a mística da relação da poesia com a magia? É claro que, dependendo do sentido que se queira dar para esses conceitos, eles podem estar próximos ou muito distantes. Se quisermos discriminar em dois extremos, diremos que o místico cristão apofático não se interessa por nenhum tipo de magia prática, desliga-se de todo apego material e sensual e só tem interesse pelo puro recolhimento e silêncio. Já o mago, embora não deixe de trilhar um percurso espiritual, não dispensa experimentos práticos, combinações alquímicas e estudos específicos visando tanto efeitos medicinais, extasiantes, quanto conquista de poderes mundanos. Ainda assim, de qual magia estamos falando? Estamos nos referindo a exorcismos xamânicos, alquimistas árabes, ocidentais, ou a filósofos herméticos renascentistas? Isso vai depender de cada momento histórico e não há algo que os una.

Jean Cohen, de início um teórico estruturalista da poesia, assim iniciou um livro mais aberto a reflexões estéticas: “A poesia é uma segunda potência da linguagem, um poder de magia e de encantamento cujos segredos a poética tem por objectivo descobrir" (CoHEN, 1987, p. 7). Ele não é o único especialista em poética rigoroso e considerado, em datas mais recentes, a caracterizar a poesia como mágica, e a colocar como tarefa da poética um exercício de decifração de segredos mágicos. Mística ou mágica, a poesia é sempre enigmática, hoje e ontem. 
Por conseguinte, pode ser interessante, aqui, observar como teóricos clássicos da poesia (ou "poétologos", termo que aparece em alguns historiadores da literatura, como LIMA, 1995, p. 55, 77, 82, 83, 85, 88; BERGENGRUEN, 2003, p. 39) apontaram nela elementos mágicos. Proponho expor e comparar três deles Platão, Opitz e Novalis -, que apontaram como elemento essencial da poesia uma complexa relação entre beleza, musicalidade e magia, para esclarecer algo da confusão atual e poder refletir melhor sobre as consequências desse gesto teórico.

\section{Platão}

No período pré-filosófico, Homero e Hesíodo eram consagrados como as principais fontes de aprendizado, saber e prazer cultural. Bem ao contrário da experiência pós-moderna global, a poesia, na Grécia, era tão presente na vida das pessoas quanto o cinema é hoje, dominando tanto o espaço pedagógico quanto o do entretenimento. Sabe-se que, com Platão, a filosofia começa a tratar da poesia competindo com seu espaço e prestígio, condenando-a para fora da república ideal. Era preciso que a racionalidade conquistasse seu diferencial e afrontasse a aceitação fácil da irresistível fantasia. O que pouco foi notado, no entanto, é que um dos motivos centrais da condenação é o fato de a poesia ser uma "paixão de nossa infância" que enredou o homem grego numa paideia ditada por um relaxamento moral. Sua atratividade exige do filósofo um difícil esforço de desligamento, para que não prejudique seu "governo interior". É

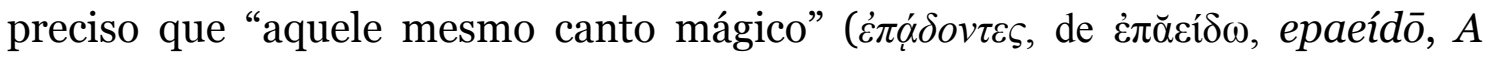
república, em Platão, 2001, p. 474, 608a) seja ouvido com muita precaução. Toda desconfiança é pouca. A única maneira de sair dessa "sedução natural" (Platão, 2001, p. 461, 601b) é desmascarar os fantasmas de aparência criados pelo poeta, pois ele não passa de um imitador. $\mathrm{O}$ amor pela poesia é danoso à alma, inoculado pela educação tradicional e reforçado pela saudade da tenra idade. São os muitos fatores em conjunção que complicam a resistência do

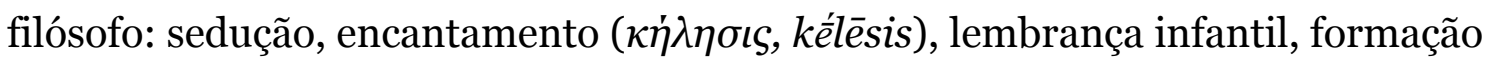
fundamental e beleza aparente. Tudo isso exige um firme controle da razão contra sua tentação, sua influência letal (MurRAY, 1995, p. 23). O poeta instiga o excesso emocional e erótico. O homem razoável é aquele que restringe tanto a tristeza quanto o prazer, pois “usa a razão para controlá-las” (BELFIORE, 1980, p. 130).

Ao longo do percurso dialético, Sócrates vai concluindo, na República, que o poeta se comporta como um mentiroso. Sua faculdade mágica é o poder de 
enganar: apresenta deuses como feiticeiros que se metamorfoseiam, o que é falso (Platão, 2001, p. 93, 380d, p. 98, 383a; MurraY, 1995, p. 145, 151). Como, por conseguinte, sair desse círculo tão poderoso de afeto, formação e apelo? Esse "veneno requer a medicina da verdade como um antídoto" (MURRAY, 1995, p. 188). As obras poéticas são "a destruição da inteligência dos ouvintes,

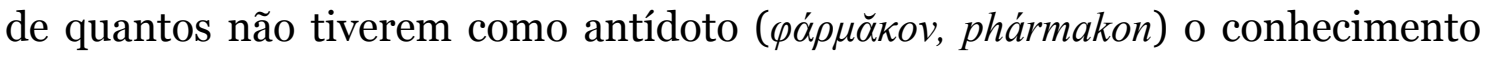
de sua verdadeira natureza" (PLATÃo, 2001, p. 449, 595b). Logo, a filosofia seria o remédio para a charlatanice imitativa da poesia, que é uma espécie de magia danosa, uma falsa medicina. Stephen Halliwell argumenta, contudo, que não é possível achar o "antídoto" filosófico proposto em 595b para o "(metaphorical) incantation (epôdê)" de 608a (HALliWELL, 2011, p. 185). Sócrates declara ser tão difícil sair da influência desse "incantation" que mesmo o filósofo precisa também se servir de elementos "self-protective incantations or spells"(HALLIWELL, 2011, p. 185) para, justamente, sair da cegueira mágica, o que se conjuga com a proposta ascensional do Banquete, do uso da beleza exterior como primeiro degrau, e das ironias de Cármides (HALliWELL, 2011, p. 184-185, 199-200). Elizabeth Belfiore, conjuntamente com outros especialistas (como Romilly, Edelstein e Derrida) observa que a filosofia se opõe à magia enganosa dos sofistas e poetas porque ela leva à ilusão. Mas, para sair da ilusão, Sócrates pretende revidá-la com uma outra magia, uma "contramagia" que se torna aniquilação obstinada de todas as ilusões (BELFIORE, 1980, p. 128). Se o mágico domina sua vítima não a permitindo usar de sua vontade, "Sócrates usa sua habilidade contra sua própria vontade e torna suas 'vítimas' capazes de agir voluntariamente" (BELFIORE, 1980, p. 133). Em outras palavras: Sócrates é um pré-iluminista. Em Cármides, Marcus Reis Pinheiro diz que o encantamento de Sócrates se dá com belos discursos dialéticos que fazem nascer a sensatez na alma (PINHEIRo, 2005, p. 178). Mas, para que tal "magia da razão" tenha efeito, para que Sócrates possa curar a dor de cabeça de Cármides, é preciso que ele entregue sua alma, irrestritamente, para o espírito de questionamento dialético. Nesse caso, a psicagogia (conduação da alma) da filosofia exige uma entrega e disposição completa a ela para que o aprendiz, comovido, ouça, de forma adequada, os argumentos racionais (PInHEIro, 2005, p. 178-9). Nesse caso, não é sempre que o sujeito deve se colocar sob suspeita. Quando aparece o encantamento que leva à liberdade, e não ao aprisionamento sem fim, o aprendiz deve se deixar levar pelo encanto com o uso da própria razão.

O mais interessante da argumentação de Marcus Pinheiro é que, na passagem 162d, Crítias se irrita quando Cármides fala coisas que não condizem 
com o que o seu tutor lhe ensinou, assim como um ator, ou orador, apresenta mal os poemas de um poeta. Pinheiro insiste que, nessa passagem, comprova-se o quanto é imprescindível, para Platão, que o pupilo faça a experiência da aprendizagem e não a tome superficialmente, assim como o ator não pode representar sem incorporar o texto poético (PINHEIRO, 2005, p. 181). De forma semelhante, no Fedro, toda a argumentação contrária à escrita e a favor da transmissão oral ocorre porque Platão defende a importância "da vivência pessoal nas conversas filosóficas” (PINHEIRO, 2008, p. 72). Só há verdadeiro conhecimento de um tema se ele estiver "inscrito" na alma, e a leitura, por si só, desvincula "o saber da vivência necessária para se apossar dele" (PINHEIRo, 2008, p. 74). Assim, parece que Platão, de forma bem complexa, admite que haja um envolvimento encantador indispensável para o aprendizado filosófico, cujo exemplo se evidencia, ironicamente, no envolvimento que o poeta tem com sua própria obra.

Isso implica, sem dúvida, em ser a filosofia também poética, também retórica, na prática literária de Platão. Assim, pelo fato de a filosofia não ser um remédio totalmente eficaz, ela não só faz uso de recursos poéticos como não pode abrir mão deles: todo o ritmo do diálogo platônico, suas idas e vindas, o assentimento constante do interlocutor de Sócrates e os momentos de incompreensão, que exigem dele prolongamentos, comprovam uma certa composição verbal musical para propósitos racionais.

É importante destacar que, para Platão, são os elementos musicais da poesia que lhe conferem poderes perigosos. Ele frequentemente afirma que não se deve levar a sério o conteúdo do que é dito pelos poetas - grave é o seu efeito, vindo da musicalidade aduladora, formal e cancional. A união da música com a poesia torna os homens frouxos, femininos, e algumas afirmações de Homero sobre os deuses e algumas caracterizações dos heróis são maus exemplos morais.

Essa sedução irracional da mente, que vemos num diálogo da fase média como a República, já aparece num diálogo inicial, não a partir da condenação do simulacro como um tipo de imitação, mas a partir de um desconhecimento técnico e científico de atividades práticas e uma entrega ao magnetismo do êxtase (HAlliWELl, 2011, p. 205), do "poder divino (theía dynamis)" que leva à inspiração, no Íon (PlATÃo, 2011, p. 13, 37, 533d). Claudio Oliveira, tradutor da nova edição brasileira de Íon, explica que essa entrega às musas, que falam pelo poeta e pelo rapsodo, colocam o poeta no lugar da sabedoria; Sócrates, contudo, 
quer referir-se aos próprios homens e buscar a construção de um saber (PLATÃo, 2011, p. 13). No ensaio que se segue ao diálogo, Alberto Pucheu, no livro, sublinha que Sócrates começa admitindo haver técnica em Íon (530b-c), e só com base num reconhecimento inicial da habilidade do rapsodo é que, em seguida, põe-no em dúvida, e o obriga admitir ter sido injusto (posfácio de Pucheu, Platão, 2011, p. 77). Pucheu considera que a filosofia é, com isso, "atópica”, desconstrói noções tradicionais. Contudo, defende, justamente, que a crítica filosófica não deixa de elogiar o poeta por seu "caráter divino, que, extático e entusiástico, através do ritmo e da harmonia dos versos, tira o poeta, o rapsodo e o público de si, fazendo aflorar o "pensamento" [a dianoia] de tais versos" (PlatÃo, 2011, p. 78). E, para além da polêmica entre filosofia e poesia, Platão estaria querendo, antes de tudo, levar-nos a pensar no meio da discussão agonística, ao mesmo tempo em que estaria praticando um desguarnecimento da fronteira entre os dois, tencionando as diferenças sem deixar de fazer com que uma se contamine pela outra. De certa forma, Belfiore, Pucheu e Halliwell se encontram, pois o professor da universidade escocesa de St. Andrews argumenta como Sócrates se vê forçado a participar da beleza poética para tornar-se livre dela. Em outras palavras, o poder da palavra não só é dificilmente superável, como, mesmo buscando dela se afastar, é necessária alguma participação em seus encantos.

Mas de onde Platão tirou, afinal, a ligação entre poesia e feitiço? Na Grécia antiga, essa visão advinha provavelmente do mito de Orfeu, que exercia poderes mágicos sobre a própria natureza. O termo $\theta \dot{\varepsilon} \lambda \gamma \omega$, [thélgō], descreve geralmente o que é mágico e potencialmente perigoso nos efeitos da canção (MURRAY, 1995, p. 208). Dodds explica que Platão, em relação aos próprios poetas antigos,

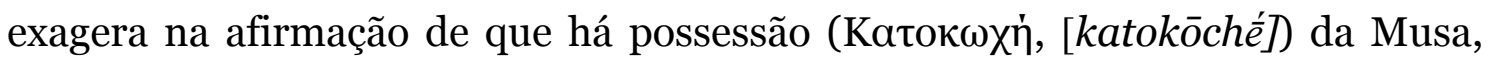
pois geralmente os poetas pedem ajuda a elas não no modo de dizer, mas na memória do conteúdo, para informações precisas de batalhas, ocorrências em geral. As musas tudo veem e sabem e, num tempo em que não havia fartura de documentos escritos, muito menos bibliotecas, os poetas estavam conscientes da falibilidade da tradição. Em especial, pediam uma "visão" do passado para que pudessem descrevê-lo melhor. Os poetas, enquanto depositários dessas inspirações, tinham preparação profissional e faziam o trabalho consciente de transformar os “flashes” em linguagem. Se Píndaro pede para musa o oráculo, para que ele seja seu intérprete (BOWRA, 1964, p. 240, fr. 137), encontramos aqui uma clara pista do antigo parentesco entre poeta e adivinho. No entanto, o poeta só pretende atuar como intérprete da musa e não ser possuído. Assim 
sendo, Platão força a ideia de que o poeta não tem a mínima ideia do que está falando (DODDS, 1960, p. 85-87).

Embora poetas como Homero não estejam diretamente ligados ao culto dionisíaco, sendo, antes, devotos de Apolo e Atena, Platão, no Íon, vê em sua performance uma espécie de transe báquico. Logo, podemos resumir a condenação de Sócrates-Platão nos seguintes termos: se o poeta tem alguma técnica, ela é prejudicada pela possessão, e sua ignorância leva-o a mentir, seduzir, enganar com belas imagens e melodias verbais, que possuem fortes poderes mágicos.

Uma questão que permanece, nesse caso, é: por que Platão vê tantas qualidades negativas no efeito encantatório se ele vem, no final das contas, dos deuses? Uma resposta possível: esse tipo de transe mostra que Dioniso não é confiável, talvez mesmo as musas não o sejam, ainda que, por outro lado, há momentos em que Platão os veja de forma positiva. Ele atesta o quanto o homem ainda é dependente de deuses que pretendem manter tal subordinação, cujo gozo é muito suspeito. Platão quer que o homem ganhe a ajuda apolínea para se tornar senhor de si, enfim, em termos kantianos, para sair de sua menoridade. Por isso, a repulsa de Sócrates por esse estado extático do poeta vem de sua falta de critério racional, isso o leva a espalhar falsos ensinamentos morais, que deveriam ser motivo de grande cuidado e responsabilidade. Estamos nos primórdios de uma mentalidade que, no futuro, julgará que magia leva, portanto, ao charlatanismo. Platão está num estágio central de ataque à magia feito pelo esclarecimento, e a vítima, aqui, é a poesia. É por isso que a literatura, tempos depois, encarnará, para a filosofia pós-metafísica, o lugar por excelência de crítica (ou desconstrução) da razão instrumental.

Vale a pena, aqui, retomar as afirmações dos teóricos recentes da poesia. Considerando que eles se confundem, por vezes, falando ora de mística, ora de magia, ao qualificar elementos extraordinários da poesia, convém diferenciar a dita magia poética da mística a partir dos dados expostos. A poesia mística (medieval, renascentista, barroca) não prescinde de contato com a materialidade e a corporalidade, contudo, o que mais faz é mobilizar uma série de imagens simbólicas com vistas a, por meio delas, adentrar no mundo transcendente, que, sem esse recurso, seria ainda mais inefável do que é. O místico entra num processo de purificação dos apegos mundanos e interiorização, inflamando-se de amor (que é ágape, mas tem muito de eros, um erotismo explicitamente espiritualizado) para que a alma consiga se aproximar 
o máximo possível de Deus, de modo que Ele conceda, também por amor, num ímpeto tão apaixonado quanto o anseio da alma, estados de graça.

Embora a ascese do místico envolva um enorme controle das paixões mundanas, o que ele busca é também um ápice de entrega erótica espiritual. $\mathrm{E}$ uma das fontes privilegiadas do seu percurso anagógico é, sem dúvida, o Banquete de Platão, que, por sua vez, é influenciado pelos cultos órficos.

O poeta grego, contudo, não é um asceta órfico. Diferentemente do que pensa Platão, ele também não é um possuído báquico, nem dedica sua vida a se entregar à musa. Ele a serve, sim, mas geralmente só pede sua ajuda, e tem muito trabalho formal, com consciência inspirada, em torno da composição dos versos, das melodias, servindo-se de recursos mnemotécnicos e interpreta, com isso, as visões que recebe. Enquanto criador e performer, ele se entusiasma e encontra seus êxtases, mas seu deus não é tão exigente, asceticamente, quanto o deus cristão. A ascese do poeta grego se dá em torno da materialidade das linguagens artísticas empregadas: língua, canto e performance; e ele se esmera para oferecer isso ao público, que é extremamente atraído por seus encantos verbais e melódicos. Se o poeta faz alguma magia, ela vem das aparências que pode pintar com habilidades verbais.

O místico autêntico, ao contrário, não deve ser um performer, nem de seus poemas nem de seus êxtases, mas também não é um asceta isolado: Deus exige dele obras, depois de todo o itinerário anagógico. Tais obras são efetivadas por piedade, para ajudar outras almas, e não para atrair e agradar um público, ainda que não possamos ignorar o considerável alcance de seu carisma.

Finalmente, o poeta de Platão é condenado pelos filósofos da república, mas só na ficção filosófica. Na Grécia, eles tiveram grande prestígio, antes e depois de Platão, e logo outros grandes filósofos, como Aristóteles, corrigiram a querela e buscaram conciliação. O poeta passou a ser visto com desconfiança, sim, por uma influência posterior de Platão na Igreja e, mais tarde, foi condenado, de fato, à orfandade em meio ao mercado, pela tecnocracia positivista moderna. Os místicos, por outro lado, foram motivo de constante condenação e censura eclesiástica, mesmo que não tenham intencionado ser, de maneira alguma, heréticos. Voluntariamente heréticos só serão, tempos mais tarde, poetas modernos profundamente influenciados pela mística e pela magia culta (e filosofia oculta), como Blake, Rimbaud, Nerval... 


\section{MARTIN OPITZ}

Agora vamos dar um longo salto temporal. Grande humanista e primeiro poetólogo alemão, considerado o pai da poesia barroca alemã, cuja influência foi longa e generalizada, Martin Opitz publicou Buch von der Deutschen Poeterey ("Livro da poética alemã") em 1624. Opitz leu e incorporou bastante a interpretação hermética de Ficino do Banquete de Platão (1484) e toda sua difusão, especialmente no filósofo hermético alemão Agrippa von Nettesheim (cuja obra De occulta philosophia é de 1510). Agrippa faz parte do neoplatonismo renascentista, na elaboração de uma magia culta, "reformada e erudita”, nas palavras da historiadora Francis Yates (1995, p. 30), que foi central na cultura da época. Ele teve papel importante na poética de Opitz, que, por sua vez, foi lido por todas as gerações de poetas alemães subsequentes. O professor ginasial de Silesius, Christoph Köler, foi o primeiro biógrafo de Opitz.

Logo no início, ele diz que a "poética não é outra coisa senão uma teologia oculta (verborgene Theologie)/ e ensina sobre coisas divinas" (OPITZ, 1689, cap. II, tudo o que cito em outra língua é tradução minha). A poesia é a "primeira filosofia", e os poetas são "pais da verdade”. Ele descreve os primeiros grandes poetas como homens que tudo sabiam e podiam (CERSOWsKY, 1990, p. 27), munido de fartos exemplos da literatura antiga, e chega a citar Platão (que discordaria frontalmente dessa visão) como um poeta trágico.

Se Platão via no poeta um charlatão que misturava saberes distintos e enganava sobre todos eles, Opitz via a mesma habilidade poética como um "elo" entre distintas esferas (CERSOWKY, 1990, p. 31). O poetólogo alemão segue aqui outra poética, a Defesa da poesia (1583) do inglês Philip Sidney, que afirmava ser o poeta o "monarca de todas as ciências" (SIDNEY, 2002, p. 109). O poeta precursor e originário aqui é Zoroastro, mas também Orfeu é citado. Se Platão via em grande parte negativamente o poder divino do poeta, Opitz o cita de forma explícita como um "furor divino" redondamente positivo (göttlichen Furor, OpITZ, 1689, cap. VIII), que serve como prova da ascensão do homem a Deus. No fascinante livro sobre poéticas do século XVII, Magie und Dichtung, Peter Cersowky demonstra de que forma as caracterizações elevadas que a filosofia oculta (em especial Agrippa) dava ao "mago" eram transpostas, por diferentes poéticas, como a de Sidney e de Opitz, para a figura do poeta.

O pendor do poeta para mediar os diferentes saberes é visto com bons olhos, especialmente porque a filosofia renascentista estava imersa no princípio 
da analogia, que é uma das formas da similitude que Foucault viu como saber da semelhança (FoUCAULT, 2000, p. 23, 48).

Schafferey Von Der Nimfen Hercinie, de 1630, é tido como o primeiro romance pastoral alemão, modelo para a toda a literatura pastoral subsequente. Vários pastores conversam sobre poesia, encontram-se com ninfas das fontes e são informados dos mistérios das montanhas (STEINIG, 2006, p. 74). Dizem que a poesia é capaz de revelar conexões ocultas entre micro e macrocosmos, plantas e estrelas, e a união amorosa entre diferentes esferas (CERSOWKY, 1990, p. 95). A doutrina erótica neoplatônica serve para unir o poder das constelações com os hábitos dos homens. O amor, que une o diferente por relações de semelhança, é apontado, então, como mágico. Há uma magia naturalis nos poemas de Opitz, introduzida por figuras poéticas como ninfas em meio ao elemento água que, pelo fluxo do rio, mostra os "cursos ocultos da riqueza da terra". As ninfas desvelam as "coisas singulares da natureza" ao pastor (CERSOWKY, 1990, p. 96; OPTIZ, 1746, p. 667, 669).

Salta à vista o enorme contraste entre a recusa platônica da magia poética e a divinização do poeta feito mago filósofo e mestre da verdade. O objetivo de Opitz é dizer que a língua alemã contém alto potencial poético e estimular seus compatriotas a ler poetas antigos, poetas italianos, franceses e ingleses e elevar a literatura alemã. Ele parece glorificar os poetas em geral e chamar atenção de seus compatriotas para a sua importância. Por isso, o grau de elevação do poeta na defesa da poesia, junto com Sidney, supera em muito o tom moderado e crítico de poetólogos antigos, como Horácio e Longino.

Mas, além disso, Opitz está imerso numa cultura neoplatônica e hermética em que a valorização da natureza, a necessidade de sair de um paradigma da abstração e pureza, começa a se instaurar. A retomada de pressupostos mágicos em meio ao erudito produz novas cosmologias, estimula filósofos a incrementarem as esferas da antiguidade neoplatônica e teológica (de PseudoDionísio) com elos mais variados e complexos entre o mundo natural, celeste e supraceleste. Se ao Platão do Banquete a anábase anagógica só interessa na medida em que a alma se distancia da beleza material, para a poética renascentista surge a relevância da produção de um conhecimento dos elos entre os degraus de ascensão. Isso justifica a importância do poeta como uma figura capaz de desvendar conexões secretas. Por isso, não só a magia é aqui positivada (mesmo que haja todo um conflito eclesiástico em torno dela, o que obriga os filósofos herméticos a sempre diferenciarem sua magia da magia 
demoníaca, negra, falsa ou vulgar), como o mago mesmo torna-se modelo para a valorização do poeta, de modo que sua própria magia verbal vira um ponto especial a seu favor.

Vale frisar, portanto, que o místico católico em geral não se encontra dentro dessa magia naturalis, não quer produzir nenhum empoderamento mágico, nem um conhecimento específico da natureza. Sua contemplação da materialidade é sempre um espelho do livro divino para se aproximar do mistério trinitário com o coração. Ao mago renascentista, contudo, interessa a produção do conhecimento desses elos. Ainda que suas crenças mágicas o distanciem bastante de um cientista, Yates argumenta que foi por causa do interesse pelos elementos naturais despertado pelo mago que a ciência empírica, enfim, foi possível, logo em seguida (YATES, 1995, p. 497-500).

A poesia de João da Cruz e Teresa de Ávila estão, nesse caso, muito distantes, literalmente, da de Opitz, no mundo do catolicismo espanhol, por mais conflitos que tenham com a contrarreforma. Embora Silesius fosse um católico convertido, estava num ambiente mais próximo desse hermetismo, podendo ser visto, aqui, como uma espécie de mediador. Não à toa, como vimos acima, ele se refere a noções alquímicas de Paracelso para falar da relação entre a trindade divina e natureza.

A poesia pastoral de Optiz não pode ser igualada, contudo, à magia poética grega. Ela deriva de uma série encadeada da tradição escrita desse gênero. Quando fala de ninfas, já está se referindo a uma leitura erudita dos antigos. Por isso que a própria magia da Renascença é, em suma, culta.

\section{NOVALIS}

Saindo da Renascença e entrando nos princípios do romantismo, que dialoga com essa literatura pastoral, aparece o romance poético fragmentário Heinrich von Ofterdingen (1800), de Novalis, que o germanista Maximilian Bergengruen chama de "texto poetológico" (BERGENGRUEN, 2003, p. 41). Leitor de Paracelso, Ficino e Jakob Böhme, Novalis, no livro, narra como os homens davam sentido intenso à natureza. Eles podiam fazer prodígios inacreditáveis, que hoje soam fantasiosos (Novalis, 1977, tomo 1, p. 210; BERGENGRUEN, 2003, p. 40). O saber dos sinais das estrelas e da natureza são uma ciência do mistério, 
abrem a "vida secreta das florestas" (Novalis, 1977, tomo 1, p. 211; BERGENGRUEN, 2003, p. 41).

Percebe-se aqui a mesma linhagem mágico-pastoral, agora a serviço de uma visão fantástica da natureza. A natureza não é apenas mágica por estar em relação com outras esferas superiores, ela guarda mistérios que a vida metropolitana e burguesa moderna nascente está desaprendendo. A nostalgia romântica aparece como um retorno do poder perdido de um homem mais enraizado no ambiente natural. Magia passa a ser não só um conhecimento secreto, mas a abertura para um mundo encantado que foi esquecido e abandonado. Novalis não se preocupa, como os filósofos herméticos, em elevar a magia à ciência erudita: ele pretende recuperar a ingenuidade da infância da humanidade que ainda guarda um olhar capaz de se maravilhar novamente; não sem motivo, tudo o que ele escreve é impregnado de uma musicalidade encantadora, anterior a secura estilística dos escritos científicos, comprovando, aliás, as suspeitas de Platão do thélgō, canto mágico.

Bergengruen retoma a conexão do pensador romântico com o saber da semelhança: "Na descrição de Novalis dos tempos antigos aparece uma característica importante da magia natural: o cruzamento de microcosmo e macrocosmo através de simpatia, a doutrina do efeito secreto da natureza”. O mágico é um servidor de Deus que coloca em movimento os efeitos naturais enquanto mediador do céu e da terra. Cantores e poetas contam também como mágicos (a raiz platônica aqui é clara), e o "poeta" a que os personagens do romance se referem é posto, portanto, em contato imediato com a tradição da magia natural (BERGENGRUEN, 2003, p. 42).

A magia cristã de conciliação entre o mago e a teologia vigorava já em Ficino, em continuidade a já mencionada assimilação de poderes mágicos do poeta.

Há uma passagem que pretende esclarecer a especificidade da poesia, em meio ao arrebatamento lírico constante. Os mercadores, personagens dessa ficção, dizem que a música depende da habilidade de tocar um instrumento e saber tirar o som dele, a pintura tem como grande mestra a natureza, e procura experimentar formas e cores capazes de imitá-la. O poeta, contudo, é marcado como "astro especial” em sua vinda ao mundo. Enquanto nas outras artes há sempre algo de externo, a poesia não depende de instrumentos. "Na poesia tudo é interior [...] o poeta preenche o santuário interior do espírito (Gemüths) com 
pensamentos novos, maravilhosos e agradáveis". É ele que “sabe despertar, a seu bel prazer, poderes secretos, e nos oferece à percepção um mundo esplêndido e desconhecido através das palavras". "Cada sentença do poeta exerce em nós um poder mágico" (Eine magische Gewalt üben die Sprüche des Dichters aus, NOVALIS, 1977, tomo 1, p. 210).

Nesse momento, fica mais clara a diferença da magia poética romântica para a renascentista. O gênio poético tem o privilégio de falar de um lugar interior, que contém em si o acesso a mundos desconhecidos. Essa interioridade extraordinária não ocorreu em nenhum outro momento histórico. Sua capacidade de desvelar o absolutamente desconhecido e, ao mesmo tempo, produzir magia natural, mostra como o romantismo filosófico combina a liberdade e criatividade subjetiva, de matriz transcendental, com as conexões analógicas. A magia secreta não se efetua num campo conhecido, mas serve ao desejo pelo desconhecido, pela singularidade do eu que aponta para a alteridade cósmica através da linguagem, que não é um meio natural nem exterior, antes, proporciona a mediação da idealidade.

O pré-romântico alemão também se insere na ligação neoplatônica entre amor e magia: "Amor é a base (Grund) da possibilidade da magia. O amor se efetua magicamente" (Novalis, 1993, p. 255). Sabe-se que Novalis, junto com Friedrich Schlegel, estudou as filosofias de Kant e Fichte, e fez a sua versão da filosofia transcendental. Se a filosofia oculta pensava que as conexões entre as coisas se davam num cosmos fechado, a liberdade subjetiva idealista introduz no pensamento romântico uma combinação infinita de assinaturas (Signaturen), feita pelo sujeito poético. Há, nesse caso, uma modificação recíproca entre magia natural e filosofia transcendental; além disso, a teoria do organismo e especulações sobre eletricidade e magnetismo também participam dessa complexa síntese filosófica e poética. (BERGENGRUEN, 2003, p. 45-49).

Em suma, o poeta não é somente um participante passivo dos princípios da natureza: ele se serve de suas regras ativamente. Há nele uma faculdade de transformação poética do mundo por meio do poder da palavra e da fantasia, feita no processo de criação com a natureza (BERGENGRUEN, 2003, p. 50). A singularidade criativa do poeta o capacita a esse desvelamento dos segredos da natureza pela palavra.

Esse dom extraordinário do poeta aparece, em Platão, não só movido pela condenação, mas também de forma positiva. Encontramos, no Fedro, um tipo 
de loucura (mania) que não é danosa, é, ao contrário, desejável, "inspirada pelas musas": aquela que "fecunda uma alma delicada e imaculada", sendo lançada a "transportes" para celebrar a glória dos antigos e "contribuindo para a educação da posteridade. Quem acha que basta habilidade para a poesia será ofuscado pela arte poética que jorra daquele a quem a loucura possui” (PlatÃO, 1986, p, 53-54). Logo, o requisito básico para ser poeta é ser capaz de sair de si. Aqui Platão vê a possessão divina como uma qualidade inalienável do fazer poético. Ela é, até, critério de valor.

Novalis, no fragmento 111, retoma essa correlação entre poesia, magia e uma espécie de loucura afirmativa: "No período da magia o corpo serve à alma, ou ao mundo dos espíritos. / Loucura - exaltação./" A exaltação maníaca parece também estar ligada, como em Platão, à possessão espiritual, de tal modo que, se ela for compartilhada, torna-se mágica: "Loucura em comum deixa de ser loucura e se torna magia”, "todas as artes e ciências repousam sobre harmonias parciais. /Poetas, loucos, santos, profetas./" (Novalis, 1988, p. 143). Todos aqueles que saem da normalidade social, mas que são capazes de levar a sociedade a compartilhar de suas descobertas únicas, feitas sobre "harmonias parciais", isto é, sentidos pouco usuais e parcialmente inteligíveis, produzem a magia do saber. Assim, o poeta moderno carrega em si um dom somente concedido a figuras arcaicas (santos e profetas) e a indivíduos incompreensíveis (loucos). O poeta tem o poder de mudar o rumo da sociedade em que vive, fazer com que todos saiam da mundanidade e experimentem os segredos do idealismo mágico.

Se Platão vê o poeta como uma "alma delicada e imaculada", privilegiada pelos deuses, os mercadores do romance novaliano viam nele um "astro especial”. A loucura poética é uma benção divina, não é uma doença perigosa. Manifesta o potencial da exaltação e cria uma mistura singular de harmonia e dissonância entre corpo e alma, que faz surgir o poder mágico. A divinização do poeta de Novalis não se dá mais por ele ser um elo entre saberes, um mestre da verdade. Sua magia verbal é a porta para o desconhecido que pode reencantar um mundo já desencantado.

\section{PODER DE MAGIA}

Embora Opitz tenha um olhar sobre a poesia, e mesmo a poética, que pareça um pouco deslumbrado, seu tratado aborda questões de ordem estritamente técnica, com considerações sobre as diferentes formas poéticas. $\mathrm{O}$ 
lado mais objetivo, analítico e classificatório das poéticas começou com Aristóteles, desenvolveu-se com Horácio, Longino e no ensino da retórica. Manteve-se sempre no impasse entre o dom natural e inspirado e a necessidade de aprendizagem técnica, mas todos os poetólogos geralmente concordam em que é preciso ter os dois, que a técnica serve para potencializar o talento, e que não existe talento puro sem técnica. Em Opitz, a soberania da poesia está ao lado de um desejo do desenvolvimento dela na língua alemã.

Em Novalis, não há considerações analíticas sobre a forma, análises de tropos nem grandes dissertações sobre diversos gêneros e estilos. Sua poética é, ela mesma, simultaneamente lírica e filosófica. Segue a linha que considera essencial o entusiasmo divino, que Opitz chamava de furor, mas que, agora, dáse a partir de um sujeito transcendental livre, pronto para criar a partir do infinito. Por isso o sentido da palavra "magia" em Novalis ganha a ideia de algo fantástico e fantasioso, fora da cotidianidade, que não aparecia numa sociedade como a grega, onde ela fazia parte de práticas populares dominantes, nem da renascentista, que busca reformá-la a partir de uma tradição escrita com noções teológicas e filosóficas.

Retomemos a frase de Cohen: "A poesia é uma segunda potência da linguagem, um poder de magia e de encantamento cujos segredos a poética tem por objectivo descobrir" (COHEN, 1987, p. 7). Parece que o sentido de magia aqui é mais devedor do maravilhamento de Novalis do que do aspecto perigoso e danoso de Platão, momento em que o esclarecimento precisa se destacar de qualquer mentalidade confusa, ou do desejo de empoderamento da natureza da filosofia oculta, momento em que o esclarecimento ainda quer retomar seus elos simpáticos com a natureza, antes de, no iluminismo, chegar à separação definitiva. "Segunda potência" não está aqui no sentido de algo menor, pelo contrário, é a potência secreta, oculta, que só a poesia é capaz de acessar, e só a poética é capaz de decifrar. Portanto, a "ciência" da poética, ao analisá-la tecnicamente, não a neutraliza, não faz a anatomia de um cadáver, antes, quer, mais uma vez, participar desse poder misterioso. Seu desvelamento técnico não é desencantamento, é outro tipo de revelação: é um esclarecimento que quer se reconciliar com os mistérios da natureza. Parece que ainda não há melhor mediador, para isso, do que a poesia. Ela continua, apesar dos inúmeros reveses do mundo moderno, guardando em si os poderes da magia verbal. 


\section{REFERENNCIAS}

ÁVILA, Teresa de. Escritos. Caminho de Perfeição. Vida, Fundações Castelo interior. São Paulo: Loyola, 2001.

BERGENGRUEN, Maximilian. "Magischer Organismus. Ritters und Novalis' 'Kunst, die Natur zu modificiren'". in: HERMANN, Britta et al. (org.). Ästhetische Erfindung der Moderne? Perspektiven und Modelle 1750-1850. Würzburg: Königshausen \& Neumann, 2003, p. 39-54.

BELFIORE, Elizabeth. "Elenchus, Epode", and Magic: Socrates as Silenus. Phoenix, vol. 34, n. 2, p. 128-137, verão, 1980.

BINGEMER, Maria Clara. Teresa de Ávila, uma mulher apaixonada. Jornal do Brasil, 19 fev. 2015. Disponível em: <http://www.jb.com.br/sociedadeaberta/noticias/2015/02/19/teresa-de-avila-uma-mulher-apaixonada/> Acesso em: 24 abril 2016.

BOWRA, B.M. Pindar. Oxford: Clarendon Press, 1964.

CERSOWSKY, Peter. Magie und Dichtung : zur deutschen und englischen Literatur des 17. Jahrhunderts. München: W. Fink, 1990.

COHEN, Jean. A plenitude da linguagem. Teoria da Poeticidade. Coimbra: Almedina, 1987.

DODDS. E.R. Los griegos y lo irracional. Madrid: Revista de Occidente, 1960. FOUCAULT, Michel. As palavras e as coisas. Uma arqueologia das ciências humanas. São Paulo: Martins Fontes, 2000.

FRIEDRICH, Hugo. Estrutura da lírica moderna. São Paulo: Duas Cidades, 1978.

HALLIWELL, Stephen. Between ecstasy and truth: interpretations of Greek poetics from Homer to Longinus. Oxford: Oxford University Press, 2011.

HANEGRAAFF, Wouter J. Dictionary of Gnosis and western esotericism.

Leiden: Brill, 2006.

LAUFHÜTTE, Hartmut. TITZMANN, Michael. Heterodoxie in der Frühen

Neuzeit. Tübingen : Niemeyer, 2006.

LIMA, Luiz Costa. Vida e mimesis. Rio de Janeiro: Editora 34, 1995.

MURRAY, Penelope; PLATO. Plato on poetry. Cambridge: Cambridge University Press, 1995.

NOVALIS. SCHULTZ, Gerhard. Novalis Werke. München : Beck, 2001.

NOVALIS. MÄHL, Hans Joachim (org.). Das Allgemeine Brouillon: Materialien zur Enzyklopädistik 1798/99. Hamburg: F. Meiner, 1993.

NOVALIS. Schriften. Org. Paul Kluckhohn und Richard Samuel. Die Werke Friedrich von Hardenbergs. Stuttgart: Kohlhammer, 1977.

NOVALIS. Pólen: fragmentos, diálogos, monólogo. Org. de Rubens Rodrigues Torres, filho. São Paulo: Iluminuras, 1988.

OPITZ, Martin. Prosodia Germanica : oder Buch von der deutschen Poeterey.

Bresslau : verlegts Jesaias Fellgibel, 1689.

OPITZ, Martin. Teutsche Gedichte. Franckfurt am Mayn: Bey F. Varrentrapp, 1746. 
PINHEIRO, Marcus Reis. Filosofia, Saúde, Alma e Corpo no Cármides de Platão. Princípios. Revista de Filosofia (UFRN), Natal, vol. 12, n. 17-18, p.173 -182, jan./dez. 2005.

PINHEIRO, Marcus Reis. O Fedro e a escrita. Anais de Filosofia Clássica (UFRJ), Rio de Janeiro, vol. 2, $\mathrm{n}^{0}$ 4, p. 70-87, 2008.

PLATÃO. A Republica. Trad. Maria Helena da Rocha Pereira. Lisboa: Fundação Calouste Gulbenkian, 2001.

PLATÃO. Fedro. Trad. Pinharanda Gomes. Lisboa: Guimarães Editores, 1986.

PLATÃO. Íon. Trad. Cláudio Oliveira; posfácio de Alberto Pucheu. Belo Horizonte: Autêntica Editora, 2011.

SIDNEY, Philip. SHELLEY, Percy, Bysshe. Defesas da poesia. São Paulo: Iluminuras, 2002.

SILESIUS. O peregrino querubínico. São Paulo: Loyola, 1996.

SILESIUS, Angelus. BÖLSCHE, WIlhelm. Des Angelus Silesius Cherubinischer Wandersmann: nach der Ausgabe letzter Hand von 1675, vollständig herausgegeben und mit einer Studie "Über den Wert der Mystik für unsere Zeit". Leipzig: E.

Diederichs, 1905.

STAIGER, Emil. Conceitos fundamentais de poética. Rio de Janeiro: Tempo brasileiro, 1975.

STEINIG, Martina. "Wo man singt, da lass' dich ruhig nieder--": Lied- und Gedichteinlagen im Roman der Romantik. Berlin: Frank \& Timme, 2006.

TEIXEIRA, Faustino. O legado de Teresa e Merton - Por uma conexão entre o amor humano e o espiritual. Revista do Instituto Humanitas Unisinos, São Leopoldo, v. 460, p. 6-11, 2014.

VALÉRY, Paul. Variedades. São Paulo: Iluminuras, 1991.

YATES, Frances. Giordano Bruno e a tradição hermética. São Paulo: Cultrix, 1995 . 